\title{
Measurement of Hazardous Solid Waste Generation and Composition from Institutional Source in Padang City, Indonesia
}

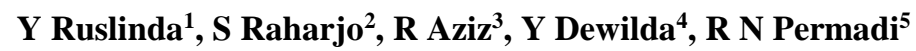 \\ Environmental Engineering Department, Faculty of Engineering, Andalas University, Limau \\ Manis, Padang, Indonesia ${ }^{1,2,3,4,5}$ \\ \{yenni@ft.unand.ac.id ${ }^{1}$, sraharjo@ft.unand.ac.id ${ }^{2}$, rizkiaziz@ft.unand.ac.id ${ }^{3}$, \\ yommi_tl@ft.unand.ac.id ${ }^{4}$, permadi.ragil@yahoo.com $\left.{ }^{5}\right\}$
}

\begin{abstract}
Hazardous solid waste (HSW) is not only produced from industrial sources, but also from other sources such as domestic, commercial, and institutional. This waste should be managed properly because it can damage the environment and endanger health. In planning a management system of HSW, data of generation and composition are needed. This study aims to determine and analyze the generation and the composition of HSW which generated from institutional sources of Padang City, Indonesia. It consists of educational, health, and office facilities. Sampling number and determination were defined based on SNI 19-3964-1994. By analyzing 37 samples with a reliability level of 97.97\%, it was found that the average generation unit of HSW of institutional sources of Padang City is $0.0807 \mathrm{~kg} / \mathrm{cap} /$ day in weight basis, or 0.06559 liters/cap/day in volume basis. Waste generation of HSW from health facilities is greater than from educational facilities and office facilities. The composition of HSW found in institutional sources based on the type of its use is generally in the form of cleaning products and body care, while based on its characteristics are corrosive and toxic. The percentage of HSW in municipal solid waste generated from institutional sources ranged from 4.4 to $6.9 \%$. Therefore, it is necessary to plan specific management for HSW from institutional sources in Padang City.
\end{abstract}

Keywords: hazardous solid waste, generation, composition, institutional sources

\section{Introduction}

Every activity carried out by humans generate solid waste, both organic and inorganic waste. Some of the waste contains hazardous and toxic materials called hazardous solid waste. Based on Republic of Indonesia Government Regulation No. 101/2014, hazardous wastes define as substances, energy, and/or other components due to nature, concentration and/or quantity, either directly or indirectly, can pollute and/or damage the environment, and/or endanger the environment, health, and the survival of human beings and other living beings. HSW is not only produced from industrial activities but also generated from household activities, commercial and institutional [1]-[3]. It is estimated that over $75 \%$ of HSW comes from the manufacturing 
industry, 5-10\% of households, and the rest from other sources. In Indonesia, the inventory of data on the generation and composition of HSW is focused on industrial waste, as well as regulations on its handling. Until now there is no definitive data on the rate of generation and composition of HSW in household waste. Similarly, HSW data in institutional waste, laboratories, workshops, pharmacies, etc. have not been well inventoried [4].

The existence of HSW is not realized by waste producers, due to public ignorance of hazardous waste. These types of waste include used a dry battery, fluorescent and used bulbs, paint packaging, cosmetics or vehicle lubricants that generally contain ingredients that cause irritation or health problems. Most of this household HSW is disposed of in mixed with other municipal waste, both in containers, transport, and final disposal [5]-[8] Although the presence of hazardous waste in municipal solid waste is relatively small [2], [6], [7] its accumulative nature poses a threat to the environment around the landfill [2], [3], [6], [7]. If HSW management is not carried out properly, the waste will cause problems for the environment even more harm than ordinary waste, such as spread through soil, water and air, and food chains, infiltrate the human body and skinned animals, respiratory and digestive diseases that interfere with kidney organs, eyes, respiratory tract, lungs, brain, nervous system, and liver [9].

The city of Padang which covers an area of $694.96 \mathrm{~km}^{2}$ is one of the developing cities in Indonesia with an increasing number of people yearly along with the growth and economic progress. One of the problems faced by the city of Padang is the problem of waste. Measurement of the amount of solid waste generation and composition of Padang city has been done from various sources. The results of related study of institutional sources that include educational, health and office facilities obtained an average unit of 1.374 liters/cap/day and the composition of solid waste consists of $34.39 \%$ of food waste; $14.19 \%$ paper; $14.92 \%$ plastic; $1.48 \%$ of textiles; $0.08 \%$ rubber; $29.12 \%$ yard waste; $0.25 \%$ wood; $0.82 \%$ glass; $1.32 \%$ cans; and $3.34 \%$ of other wastes [10]. This related study has not calculated the generation and composition of HSW. Research on HSW has carried out for domestic sources with the result of average hazardous solid waste generation as $0.004 \mathrm{~kg} / \mathrm{cap} /$ day or 0.041 liters/cap/day. The percentage of HSW in the total solid waste produced by domestic sources is $1.88 \%$. The composition of HSW based on the type of use is dominated by $51 \%$ body care and $31 \%$ cleansing products, while based on its characteristics is dominated by toxic, carcinogen, corrosive and flammable characteristic as $34 \%$ and characteristic of toxic as $12 \%$ [11].

Besides that, the generation and composition measurement of HSW from commercial sources are also has been done. The average generation of HSW from commercial sources in Padang City in weight units is $0.0022 \mathrm{~kg} / \mathrm{m}^{2} /$ day or in volume units is $0.07271 / \mathrm{m}^{2} /$ day. The percentage of HSW in total commercial waste in Padang City is $2.58 \%$. Based on the type of usage, commercial HSW is generally in the form of cleaning products $47 \%$, body cares $20 \%$, automotive products $14 \%$, paint and the like $5 \%$, pesticides, insecticides and herbicides $5 \%$ and other products $9 \%$. Characteristics of commercial HSW are corrosive $39 \%$, toxic $25 \%$, corrosive and toxic $16 \%$, flammable $10 \%$, toxic and combustible $8 \%$ and corrosive and flammable $2 \%$ [12].

In order to obtain the data of the generation and composition of HSW from other sources, this study was conducted with a focus on HSW generated from institutional sources. It is expected that the results of this research useful for further research on the planning of the HSW management system in Padang City. 


\section{Material And Method}

A research on the generation and composition of HSW from institutional sources in Padang City included literature study, primary and secondary data collection, and data processing and analysis. Primary data collection consisted of questionnaire distribution, a sampling of HSW from each institute sources, measurement of waste generation and composition of HSW from institutions in the laboratory. Secondary data collected in the form of general information of institution and number of the institution of Padang City obtained from Central Bureau of Statistics of Padang City as well as data of the result of related researches of solid waste generation and composition of the institution. These secondary data are required as a reference in calculating the number of HSW samples as well as for calculating the percentage of HSW of the institution in total institutional solid waste.

\section{I Research Location and Time}

The calculation of sample size and sampling technique of HSW from institutional sources is done based on a standard method for sampling and measurement of municipal solid waste generation and composition. According to SNI 19-3964-1994, the amount of waste samples for measurement of generation and composition is taken $10 \%$ of the number of existing facilities. By the result of the calculation with $97.97 \%$ of the level of reliability of survey, it was obtained the number of samples of 37 units of institutional sources that include educational, health and office facilities. Sampling was conducted in March-April 2017 which was done every week for 8 weeks, except for hospital which was done for 8 days in a row because of the amount of HSW generated from health facilities every day in a bigger amount. The number and frequency of HSW collection can be seen in Table 1.

Table I: Number and frequency of sampling

\begin{tabular}{lcc}
\hline \multicolumn{1}{c}{ Institutional sources } & Number of samples (unit) & Frequency \\
\hline Educational facility: & 1 & \\
\hline -University & 2 & \\
-Senior High School & 1 & Once a week \\
-Junior High School & 6 & \\
-Elementary School & 3 & \\
-Kindergarten & & Every day \\
\hline Health facility: & 1 & \\
Hospital: & 1 & \\
-State Hospital & 1 & Every day \\
-Specific Hospital & & \\
-Private Hospital & & \\
\hline Community health center: & 2 & \\
- type I & 6 & Once a week \\
- type II & & \\
& & \\
Office facility: & 5 & \\
Governmental office & 3 & \\
-Large & 1 & \\
-Medium & & \\
-Small & & \\
Private office & & \\
-Large & &
\end{tabular}




\begin{tabular}{|c|c|c|}
\hline Institutional sources & Number of samples (unit) & Frequency \\
\hline -Medium & 1 & \\
\hline -Small & 2 & \\
\hline Total & 37 & \\
\hline
\end{tabular}

The location of the HSW sampling was obtained from randomly distributed questionnaires. The selected location is a location that has given permission for the collection of HSW and is a location that is adapted to the previous research conducted by [10].

\subsection{Research Methods and Equipment}

A technical sampling of HSW, measurement of waste generation and composition based on SNI 19-3964-1994. A day before the sampling time, the plastic bag as the sample container was distributed to the institutional sources that selected as the location of the HSW sampling. Waste producers are required to dispose of HSW in the plastic bag that has been distributed for the specified time. In order to control the research, each source of the samples has informed about the waste that is categorized as HSW. Samples of collected HSW are taken to the laboratory for measurements.

Measurement of HSW generation is done in weight and volume unit based. Measurements in weight-based are carried out by weighing the HSW generated by each institution source by using scales, whereas the measurement in volume units is done by using compactor containers. Meanwhile, measurements of the HSW composition are done by separating HSW based on the types of use and the characteristics of hazardous waste referred to G. Tchobanoglous and F. Kreith, 2002 and E. Damanhuri and T. Padmi, 2010. as shown in Table 2.

Table 2: Type of use and characteristic of HSW

\begin{tabular}{l|l}
\hline \multicolumn{2}{c}{ Type of use of HSW } \\
\hline \multicolumn{1}{c}{ Composition } & \multicolumn{1}{c}{ Products } \\
\hline Cleansing products & $\begin{array}{l}\text { Floor cleaning packages, toilet } \\
\text { cleaners, glass cleaners }\end{array}$ \\
\hline Body care & $\begin{array}{l}\text { Packing shampoo, soap, } \\
\text { cosmetics, expired medicines, } \\
\text { nail cleaners }\end{array}$ \\
\hline $\begin{array}{l}\text { Automotive } \\
\text { products }\end{array}$ & $\begin{array}{l}\text { Packing oil, packing of } \\
\text { kerosene, gasoline }\end{array}$ \\
\hline Paints and alike & $\begin{array}{l}\text { Packaging paint, thinner, } \\
\text { cartridge }\end{array}$ \\
\hline $\begin{array}{l}\text { Pesticides, } \\
\text { Insecticides }\end{array}$ & $\begin{array}{l}\text { Packaging of insect killers, } \\
\text { pesticides }\end{array}$ \\
\hline Others & Battery, lightbulb \\
\hline Characteristics of HSW (**) \\
\hline Corrosive; & $\begin{array}{l}\text { Glass cleaning packages, floor } \\
\text { cleaners, toilet cleaners; }\end{array}$ \\
\hline Toxic; & $\begin{array}{l}\text { Packaging shampoo, cosmetics, } \\
\text { pharmaceuticalexpired }\end{array}$ \\
\hline Toxic, flammable; & Packaging paints, nail cleaners; \\
\hline Corrosive, toxic; & $\begin{array}{l}\text { Battery, chlorine swimming } \\
\text { pool; }\end{array}$ \\
\hline Infectious. & Medical waste \\
\hline Sources : * Tchobanoglous and F. Kreith, 2002
\end{tabular}


**E. Damanhuri and T. Padmi, 2010

\subsection{Data Processing and Analysis}

Data processing and analysis are conducted due to perform data of generation unit, the composition of HSW based on the type of use and characteristic, and calculation of the percentage of HSW in total institutional solid waste in Padang City.

HSW generation unit is obtained from the average of HSW discharges generated from the HSW sources per day divided by the number of people in the waste source. HSW generation unit is expressed in units of weight $(\mathrm{kg} / \mathrm{cap} / \mathrm{day})$ or in volume units (liters/cap/day). The calculation of the HSW generation unit using the following equation:

$\mathrm{q}=\mathrm{Q} / \mathrm{P}$

where:

$\mathrm{q}=$ generation unit $(\mathrm{kg} / \mathrm{cap} /$ day or liter/cap/day)

$\mathrm{Q}=$ waste generation $(\mathrm{kg} /$ day or liter/day)

$\mathrm{P}=$ number of people in the building (cap)

The calculation of the percentage of HSW in the total solid waste of Padang City institutions is based on the results of waste research from institutional sources by [10]. Meanwhile, for the calculation of HSW composition based on the type of use and characteristics. The composition percentage is obtained from the weight ratio of each waste component to the total waste weight, with the following equation [6][7]:

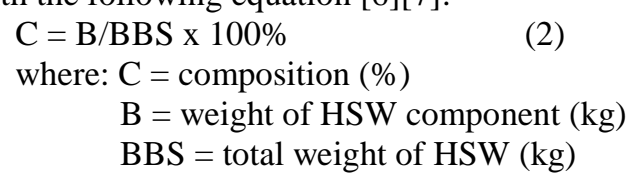

\section{Result And Discussion}

\subsection{HSW Generation of Institutional Sources}

The result of the measurement of HSW generation from institutional sources in Padang City on average is $0.00807 \mathrm{~kg} / \mathrm{cap} / \mathrm{day}$ in weight basis or 0.06559 liters/cap/day in volume basis. Health facilities produce more HSW than educational and office facilities, both in weight and volume basis. This is because health facilities generate medical waste that classified as HSW in large amounts, such as used syringe waste, bandages, used infusion bottles and expired medicines. HSW generation unit of the health facility is $0.02354 \mathrm{~kg} / \mathrm{cap} /$ day or 0.18600 liters/cap/day in weight and volume basis, respectively. Generation unit for educational facilities as $0.00008 \mathrm{~kg} / \mathrm{cap} /$ day in weight basis or 0.00152 liters/cap/day in volume basis. In-office facilities, hazardous solid waste generation as $0.00059 \mathrm{~kg} / \mathrm{cap} / \mathrm{day}$ in weight basis, while 0.00925 liters/cap/day in volume basis. The result of measurement of HSW generation from institution source in Padang City can be seen in Fig. 1.

In comparing with related studies of educational facility source, it found that the study that conducted by Elita on the campus of University of Indonesia (UI) generated HSW as 0.007 $\mathrm{kg} /$ day or 0.0836 liters/day [13], while in Padang City HSW generation of university is higher as $0.0786 \mathrm{~kg} /$ day or 0.0203 liters/day. This value differs could be caused by differences in the number of students and activities on the campus. The largest source of the HSW generator in UI campus is Faculty of Engineering, Faculty of Natural Science, Faculty of Public Health, Faculty of Medical Science, and Faculty of Computer Science. A similar condition also is seen 
in universities in Padang City, especially in the University of Andalas, the highest HSW producers from Faculty of Natural Science, Faculty of Engineering, and Faculty of Pharmacy.

Meanwhile, in health facilities, related studies have done in Dr. Soetomo Hospital Surabaya, Gatot Subroto Hospital Jakarta, and Dr. Ramelan Hospital Surabaya. Research conducted in Dr. Soetomo Hospital Surabaya obtained the average hazardous solid waste of hospital as 210.17 $\mathrm{kg} /$ day or 1,657.82 liters/day (P.M. Perdana, 2011), in Gatot Subroto Hospital as $160.4 \mathrm{~kg} /$ day [14] and in Dr. Ramelan Hospital as $70.27 \mathrm{~kg} /$ day or 610.85 liters/day [15]. The generation of HSW in these three hospitals is higher than HSW in hospitals in Padang City as $46.791 \mathrm{~kg} / \mathrm{day}$ or 307.83 liters/day. This difference could be influenced by the type of hospital, the number of employees and the patient and the activity at the hospital.

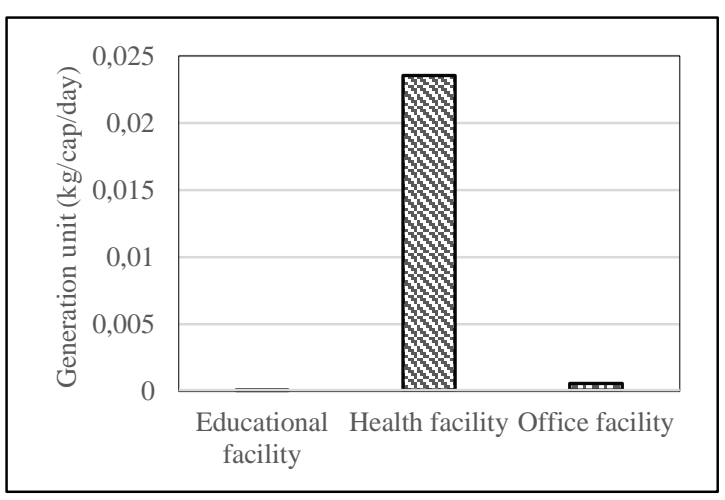

a. in weight basis

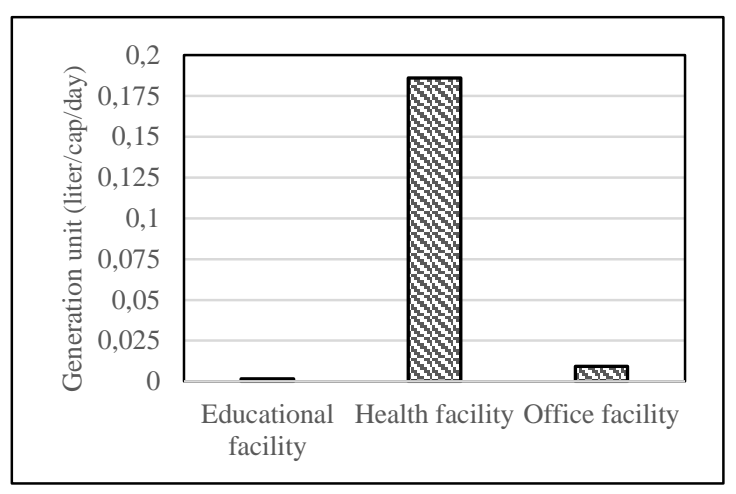

b. in volume basis

Figure 1 HSW generation unit of Institutional Sources of Padang City

\subsection{Percentage of HSW Generation in Total Waste of Institutional Sources}

In order to determine the percentage of HSW in the total waste of institutions in Padang City, the result of this study is compared with the result of the research of the institutional waste generation unit by [10], which has been projected to the same year. Table 3 shows the percentage of HSW generation in the total waste generation of institutions from each facility at the institution's source. Health facilities are the means that have the largest percentage of HSW, which is $10 \%$. For educational facilities and office facilities, the percentage of HSW is only $0.3 \%-0.5 \%$. The total percentage of total HSW in the total waste of the institution as a whole is $6.9 \%$ in units of weight or $4.4 \%$ in volume units.

Table 3: Percentage of HSW in institutional waste

\begin{tabular}{|c|c|c|c|c|c|c|}
\hline \multirow{3}{*}{ Sources } & \multicolumn{4}{|c|}{ Generation unit } & \multirow{2}{*}{\multicolumn{2}{|c|}{ Percentage HSW }} \\
\hline & \multicolumn{2}{|c|}{$\begin{array}{c}\text { HSW of institutional } \\
\text { sources }\end{array}$} & \multicolumn{2}{|c|}{$\begin{array}{l}\text { Total institutional waste } \\
\text { total* }\end{array}$} & & \\
\hline & $\begin{array}{c}\text { Weight } \\
\text { (kg/ } \\
\text { cap/day) }\end{array}$ & $\begin{array}{c}\text { Volume } \\
\text { (liter/cap/day } \\
\text { ) }\end{array}$ & $\begin{array}{c}\text { Weight } \\
\text { (kg/ } \\
\text { cap/day) }\end{array}$ & $\begin{array}{c}\text { Volume } \\
\text { (liter/cap/day) }\end{array}$ & $\begin{array}{l}\text { Weigh } \\
\mathrm{t}(\%)\end{array}$ & $\begin{array}{l}\text { Volum } \\
\text { e }(\%)\end{array}$ \\
\hline
\end{tabular}




\begin{tabular}{lllllll}
\hline $\begin{array}{l}\text { Educational } \\
\text { facility }\end{array}$ & 0.00008 & 0.00152 & 0.020 & 0.438 & 0.4 & 0.3 \\
\hline Health facility & 0.02354 & 0.18600 & 0.222 & 1.828 & 10.6 & 10.1 \\
\hline Office facility & 0.00059 & 0.00925 & 0.106 & 2.117 & 0.5 & 0.4 \\
\hline Average & 0.00807 & 0.06559 & 0.116 & 1.461 & 6.9 & 4.4 \\
\hline & \multicolumn{2}{c}{ Sources : $*[10]$} & &
\end{tabular}

In comparison to domestic or household sources, the percentage of HSW in the institution's sources is higher. Percentage of HSW in total household waste is $1.09 \%$ in weight basis or $1.88 \%$ in volume basis [11]. In this study, the percentage of HSW in total waste from institutional sources is $6.9 \%$ on a weight basis or $4.4 \%$ on volume basis. This is due to the different activities of the two sources, where at the source of the institution there are more activities that produce HSW such as in the health facilities in the form of medicine packaging, medical waste, and others. In addition, the educational facilities also found laboratory activities that produce HSW in the form of chemical packaging

\subsection{HSW Composition of Institutional Sources}

The composition of HSW from institutional sources in Padang City is classified by its type of use and characteristics. The HSW composition of this institution is expressed in \% wet weight units. The result of measurement of HSW composition from institutional sources in Padang City can be seen in Figure 2 to Figure 5.

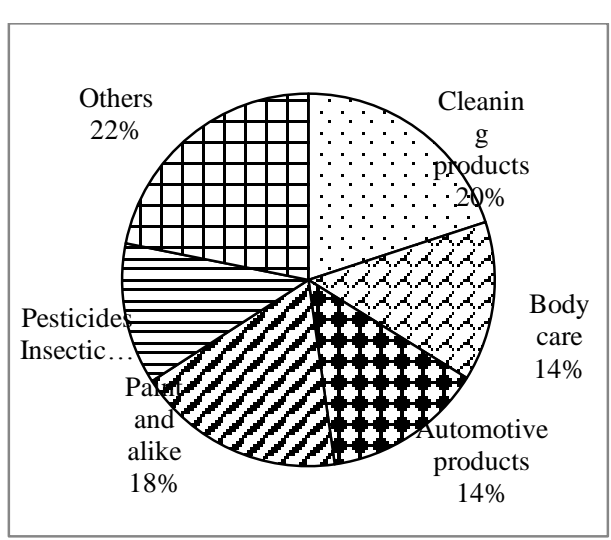

a. Type of use

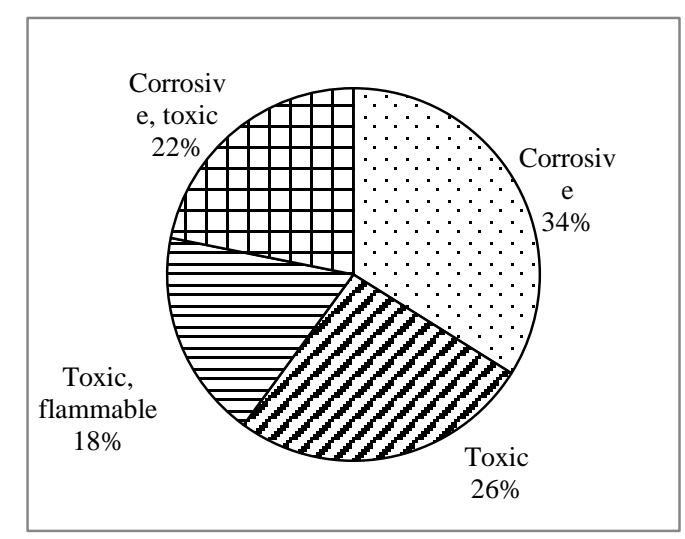

b. Characteritic 
Figure 2 HSW composition of educational facilities of Padang City

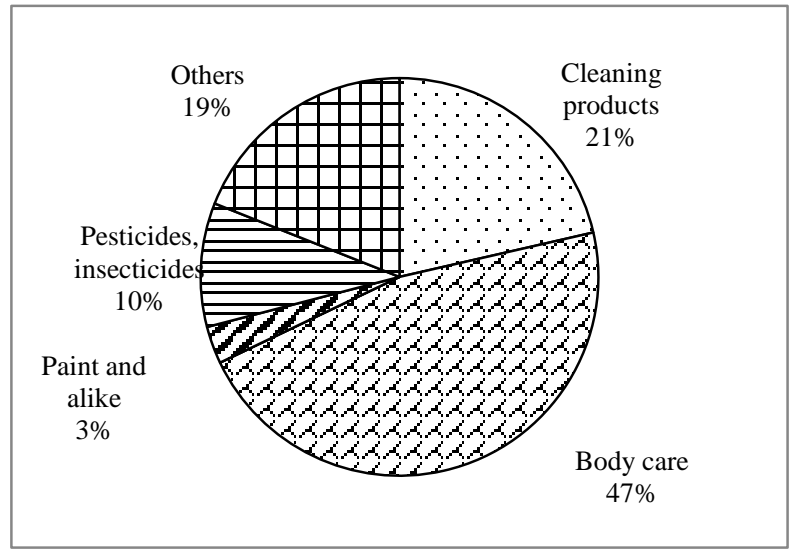

a. Type of use

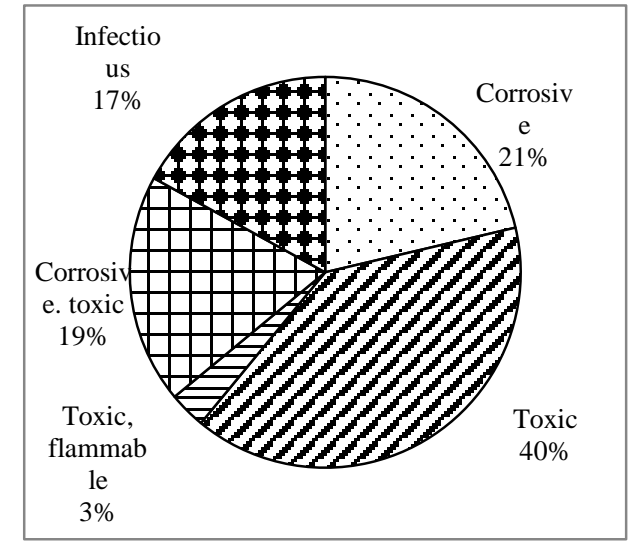

b. Characteritic

Figure 3 HSW composition of health facilities of Padang City

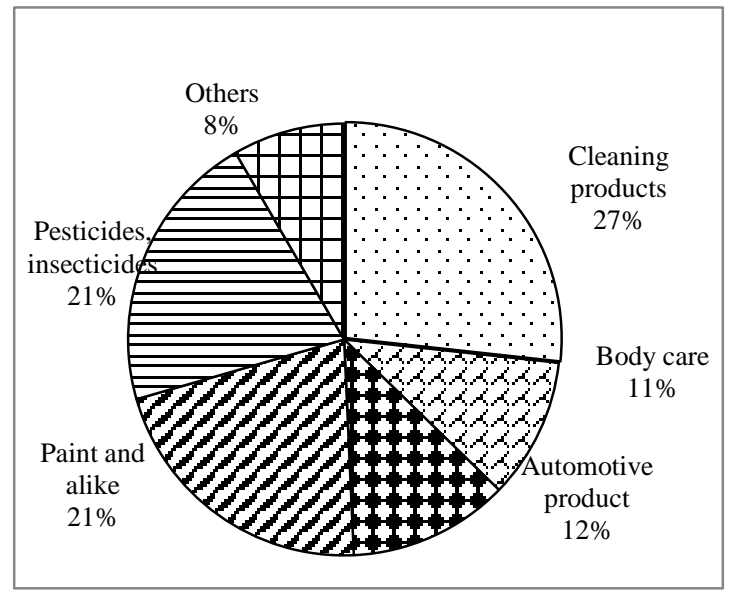

a. Type of use

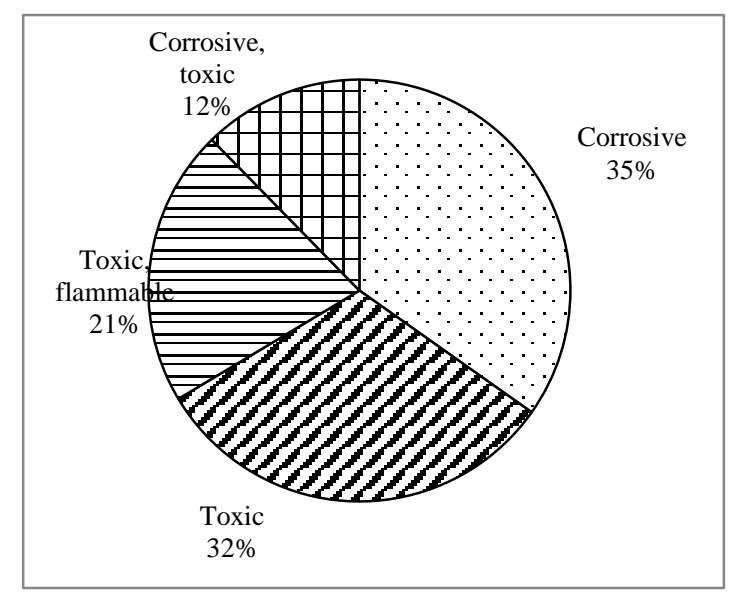

b. Characteritic

Figure 4 HSW composition of office facilities of Padang City 


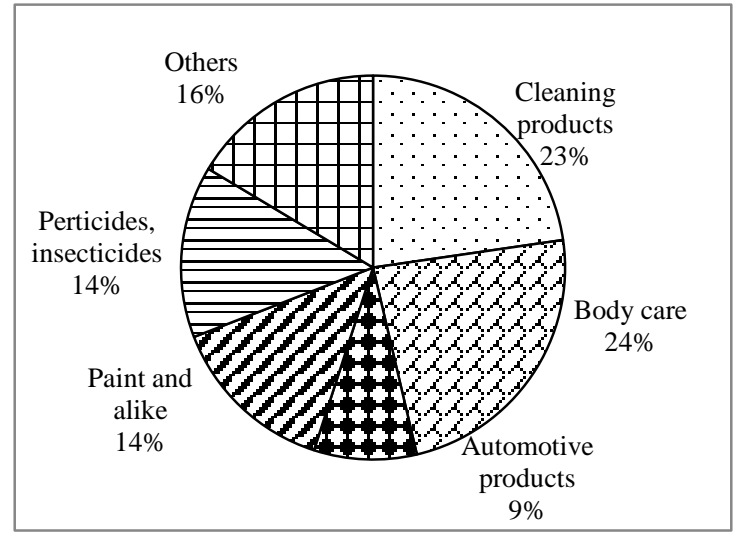

a. Type of use

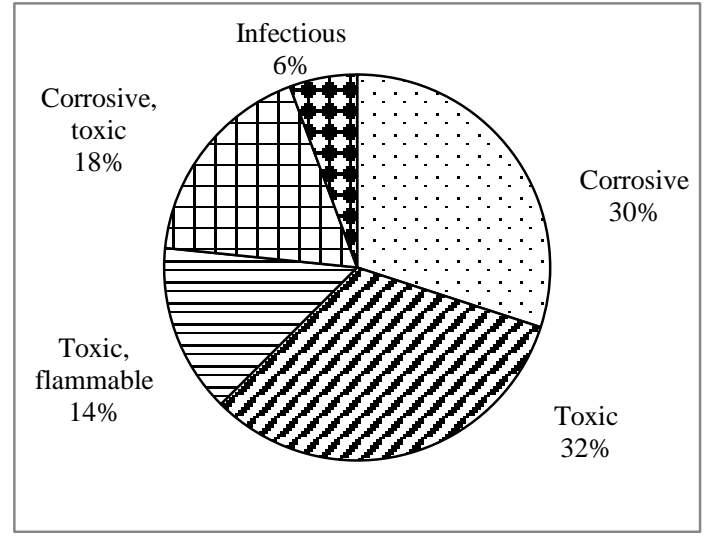

b. Characteristic

Figure 5 HSW composition of institutional sources of Padang City

From the above figures, it can be seen that in the type of use classification, HSW on educational facilities is dominated by other products by $22 \%$ such as batteries, printer cartridges, and ink packaging. At health facilities, HSW is the largest in the form of body care products by $47 \%$, such as packaging shampoo, soap, cosmetics and expired pharmaceuticals. HSW that dominates office facilities is a cleaning product of $27 \%$, such as floor cleaning, toilet cleaners, and glass cleaners. The average composition of HSW at institutional sources based on the type of use is $23 \%$ cleaning products, $24 \%$ body care, $9 \%$ automotive products, paint and alike $14 \%$, pesticides and insecticides $14 \%$, and other products $16 \%$.

The average composition of HSW on institutional sources based on its characteristics is HSW that is corrosive by $30 \%$, toxic by $32 \%$, toxic and flammable by $14 \%$, corrosive and toxic by $18 \%$ and infectious by $6 \%$. In the educational facilities and office facilities, characteristic of HSW that mostly found is corrosive about $35 \%$. This type of waste includes cleaning products such as floor cleaners, dishwashing soap, toilet cleaners, and glass cleaners. The most toxic hazardous solid waste is found in health facilities by $40 \%$, such as shampoo, cosmetic and expired pharmaceuticals. In addition, health facilities also found that HSW classified as corrosive by $21 \%$ and infectious by $17 \%$ in the form of medical waste. A similar result also found in study at Dr. Ramelan Surabaya, the characteristics of HSW found as infectious 59\%, toxic $6 \%$, and corrosive $25 \%$ [15].

Another composition of HSW found in institutional sources is toxic and corrosive by $18 \%$ obtained from products such as batteries and dry batteries found in highest quantity in educational facilities. Characteristics of HSW that are combustible toxic are found by $14 \%$ in the form of paint cans and ink bottles. This waste is found in many office facilities.

The composition of HSW based on the type of its use for the source of institutions and household sources is dominated by cleaning products and body care. The composition of both types of use is the source of the household is greater than the source of the institution. HSW consists of $51 \%$ and $39 \%$ [11], while $23 \%$ and $24 \%$ respectively from institutional sources. However, the composition of HSW based on the characteristics will obtain a different composition. In household sources, the characteristics of HSW are dominated by toxic, carcinogenic, corrosive and flammable waste by $34 \%$ [12], while the largest composition of 
HSW at institutional sources is $32 \%$ toxic and $30 \%$ corrosive. This difference influenced by the presence of medical waste generated by health facilities that exist at the source of the institution.

\section{Conclusions}

The average of HSW generation unit of institutional sources in Padang City is 0.00807 $\mathrm{kg} / \mathrm{cap} /$ day in weight basis or 0.06559 liters/cap/day in volume basis. The percentage of HSW in the total institution solid waste is $6.9 \%$ on weight basis or $4.4 \%$ on a volume basis.

The composition of HSW based on the type of use consists of $24 \%$ body care, $23 \%$ cleaning products, $16 \%$ other products, $14 \%$ paint and alike, $14 \%$ pesticides, insecticides and $9 \%$ automotive products. Meanwhile based on its characteristics, HSW from institutional sources consists of corrosive by $30 \%$, toxic by $32 \%$, toxic and flammable by $14 \%$, corrosive and toxic by $18 \%$ and infectious $6 \%$.

Based on the above data and composition, it is necessary to make special planning of HSW management system from institutional sources in Padang City.

\section{References}

[1] E. Fikri, P. Purwanto, and H. R. Sunoko, "Modelling of household hazardous waste (HHW) management in Semarang city (Indonesia) by using life cycle assessment (LCA) approach to reduce greenhouse gas (GHG) emissions," Procedia Environ. Sci., vol. 23, pp. 123-129, 2015.

[2] H. Chaib, A. Hamouda, and M. A. Muawia, "Household Hazardous Waste Management in Malaysia," Int. J. Adv. Res. Electr. Electron. Instrum. Eng., vol. 3, p. 12, 2014.

[3] A. Aprilia, T. Tezuka, and G. Spaargaren, "Inorganic and hazardous solid waste management: Current status and challenges for Indonesia," Procedia Environ. Sci., vol. 17, pp. 640-647, 2013.

[4] Y. Trihadiningrum, "Reduction potential of domestic solid waste in Surabaya City, Indonesia," in Proceedings, The 4th International Symposium On Sustainable Sanitation, Bandung, 2006, pp. 4-6.

[5] H. Lakshmikantha and N. Lakshminarasimaiah, "Household hazardous waste generation-management," in Proceeding of The International Conference on Sustainable Solid Waste Management, 2007, pp. 5-7.

[6] S. Raharjo et al., "Improvement of municipal solid waste management using life cycle assessment approach for reducing household hazardous waste contamination to environment in Indonesia: A case study of Padang City," Appl. Sci, vol. 12, p. 5692, 2017.

[7] S. Raharjo et al., "Investigation on Municipal Solid Waste Characteristics from Commercial Sources and Their Recycling Potential in Padang City, Indonesia," in IOP Conference Series: Materials Science and Engineering, 2018, vol. 288, no. 1, p. 12134.

[8] R. Slack, J. Gronow, and N. Voulvoulis, "Hazardous components of household waste," Crit. Rev. Environ. Sci. Technol., vol. 34, no. 5, pp. 419-445, 2004.

[9] H. J. Elston, "When household hazardous waste is too hazardous: A case study," J. Chem. Heal. Saf., vol. 17, no. 4, pp. 12-15, 2010.

[10] Y. Ruslinda and I. Pasimura, "Waste Generation Unit and Composition of Institutions of Padang City (In Indonesian: Satuan Timbulan dan Komposisi Sampah Institusi Kota Padang)," J. Dampak, vol. 9, no. 2, pp. 106-115, 2012. 
[11] Y. Ruslinda and D. Yustisia, "Analisis Timbulan dan Komposisi Sampah Bahan Berbahaya dan Beracun (B3) Rumah Tangga di Kota Padang Berdasarkan Tingkat Pendapatan," Lingkung. Trop., vol. 7, no. 1, pp. 21-30, 2013.

[12] Y. Ruslinda, S. Raharjo, Y. Dewilda, and S. Fimeylia, "Analisis Timbulan dan Komposisi Limbah Padat Bahan Berbahaya dan Beracun (B3) dari Sumber Komersil di Kota Padang," in Prosiding Seminar Nasional Teknik Sipil 2 (SeNaTS 2), 2017.

[13] A. . A. Elita, "Study of Waste Generation and Composition as the Basis for Design of Waste Collection System in Campus Area of University of Indonesia. (In Indonesian: Studi Timbulan dan Komposisi Sampah sebagai Dasar Desain Sistem Pengumpulan Sampah di Kawasan Kampus Un,” Universitas Indonesia, 2011.

[14] I. Sadiqul, "Management of Hazardous Solid Waste at Army Central Hospital (RSPAD) Gatot Subroto Using Incinerator (In Indonesian: Pengelolaan Limbat Padat B3 Rumah Sakit Pusat Angkatan Darat (RSPAD) Gatot Subroto Menggunakan Insinerator)," Universitas Lambung Mangkurat, 2009.

[15] A. Widhiatmoko and Y. Trihadiningrum, "Report on Study of Generation and Composition of Hazardous Solid Waste at RS TNI AL Dr. Ramelan Surabaya,” Institut Teknologi Sepuluh November, 2010. 